\title{
Correlation : Anatomical Variations of Nasal Cavity and Paranasal Sinuses and the Quality of Life Based on SNOTT-22 Score
}

\author{
Rani Rahmawati ${ }^{1 *}$, Bachtiar Murtala ${ }^{1}$, Shofiyah Latief ${ }^{1}$ \\ 1Department of Radiology, Hasanuddin University, \\ J1. Perintis Kemerdekaan No.KM.10, Tamalanrea Indah, \\ Kec. Tamalanrea, Makassar City, South Sulawesi 90245 \\ Indonesia.
}

*Email : rani.rahmawati161186@gmail.com

Received : Sept $21^{\text {th }}$ 2020. Revised : Apr $15^{\text {th }}$ 2021. Published: June $10^{\text {th }} 2021$

DOI : https://doi.org/10.22219/sm.Vol17.SMUMM1.13763

\begin{abstract}
This study aims to determine the correlation between the anatomical variations of nasal cavity and paranasal sinuses and the quality of life based on SNOT-22 score in the patients who underwent paranasal sinuses CT scan. The samples are 36 patients with age $\geq 18$ years. The method is Chi Square test / Fisher's test and Spearman's rho test. The results showed that anatomical variations of the nasal cavity and paranasal sinuses from most of the patients who underwent paranasal sinuses CT scan had septal deviation $n=29, p=0.007$ $(\mathrm{p}<0.05)$ and concha bullosa $\mathrm{n}=15, \mathrm{p}=0.029(\mathrm{p}<0.05)$. There was a significant correlation between total anatomical variation and quality of life based on SNOT-22 score in the patients who underwent paranasal sinuses CT scan $p=0.025(\mathrm{p}<0.05)$. There was no correlation between the anatomical variations of frontal cells, agger nasi cells, ethmoid bulla, uncinate process and haller cells and the quality of life based on SNOT22 score in the patients who underwent paranasal sinuses CT scan.
\end{abstract}

Keywords : The anatomical variations of nasal cavity and paranasal sinuses, SNOT-22 Score, paranasal sinuses CT scan.

Copyright (C) 2021, Rahmawati R.et al This is an open access article under the CC-BY-SA license

\section{INTRODUCTION}

CT scan is a good method for evaluating anatomical structures because it can clearly show structure of the nasal cavity and paranasal sinuses such as osteomeatal complex conditions, anatomical abnormalities, visualization, the presence or absence of pathological tissue in the sinuses and their extension. (Abul-Kasim K at all, 2011, Shindy at all 2015)

CT scan is able to provide structural anatomy descriptions of areas which is not visible through the endoscope. This examination is excellent in showing the anterior ethmoid cells, the upper two thirds of the nasal cavity and frontal recess. In this area, CT scan can show the location of the factors that cause chronic sinusitis, namely KOM. (Aghdas, 2018, Akdis at all 2015) 
Based on several study results, it was found that the most common anatomical variations on paranasal sinuses CT scan was septal deviation. Based on Budiman JB et al study, the most common anatomical variations was septal deviation in 33 patients $(70.2 \%)$, followed by concha bullosa in 3 patients (6.4\%), haller cells, and agger nasi cells. Whereas in Emilya J et al study, was found anatomical variations, such as septal deviation in 80 patients $(67.2 \%)$, followed by ethmoid bullae in 32 patients $(26.9 \%)$, uncinate processus in 25 patients (21\%), concha bullosa in 15 patients $(12.6 \%)$, haller cells in 8 patients $(6.7 \%)$, agger nasi cells in 7 patients $(5.9 \%)$ and frontal cells in 5 patients $(4.2 \%)$. Another study by Fadda $G$ et all, showed that septal deviation was the most common anatomical variation, which is $58.5 \%$, concha bullosa $49.3 \%$ and etmoid bulla $32.8 \%$. The results of these studies showed that it can be found more than one anatomical variation or even none. (SImopoulus at all 2012, Soler at all 2013, Walsh at all 2014)

Meanwhile, although the occurrence is rarely fatal, it can affect patients quality of life and disrupt working hours, especially during productive age. This creates a huge economic burden for individuals, families and those around them. Quality of life is a concept that includes both physical and psychological characteristics in a social context. In medicine, quality of life is also closely related to health. Recently, aspects of quality of life have begun to be considered in correlation with decision making for patients management. The existence of assessment tools for quality of life that relates to health status is useful to determine the impact of a disease on patient and to evaluate the effect of therapy. (Aghdas 2018, Lupoi at all 2012, Wang at all 2011 )

Furthermore, anamnesis assessment for quality of life can be carried out using a questionnaire that has been recognized as valid for sino-nasal examination, namely SNOT-22. (Alt Ja at all,2015, Banglawala at all 2015)

SNOT-22 is a modification of the SNOT-20 questionnaire. The SNOT-22 questionnaire consists of 22 statement points with 6 assessment levels. Among the 22 statements, 12 points cover the patient's physical symptoms, another 10 points cover the patient's quality of life. (Lachanas V, 2014, Leung 2014)

The nose and paranasal sinuses are organs that play an important role as the forefront of body's defense in the airway against microorganisms and other harmful substances contained in them. (Barros at all,2012, De Conde at all 2014)

Anatomical variations of the nose and paranasal sinuses such as frontal cells, agger nasi cells, ethmoid bulla, uncinate process, concha bullosa, septal deviation, and haller cells are the factors that cause drainage disorders from the nose and paranasal sinuses. These anatomical variations can cause obstruction to the osteomeatal complex (KOM) and interfere the mucocilia clearance. (Farhoods at all 2016, Fokkens at all 2012, Naido at all 2013)

Quality of life is a description of physical, mental and social status measured by the SNOT22 Score. The SNOT-22 score is a development from SNOT-20 score and cultural adaptation, 
translation and validation of SNOT-22 have been carried out using the Cronbach's alpha test = 0.936 (very reliable), reliable if $\geq 0.7$ indicates good consistency. (De Conde at all 2014, Juanda 2017)

Sinonasal Outcome Test (SNOT-22) Questionnaire Questionnaire Sinonasal Outcome Test (SNOT-22) List (Otolaryngology Head and Neck Surgery, 2004)

\begin{tabular}{|c|c|c|c|c|c|c|c|c|}
\hline No & Descriptions & $\begin{array}{l}\text { No } \\
\text { proble } \\
\text { m }\end{array}$ & $\begin{array}{c}\text { Very } \\
\text { mild } \\
\text { proble } \\
\text { m }\end{array}$ & $\begin{array}{c}\text { Mild or } \\
\text { slight } \\
\text { proble } \\
\text { m }\end{array}$ & $\begin{array}{l}\text { Moderat } \\
\text { e } \\
\text { problem }\end{array}$ & $\begin{array}{c}\text { Severe } \\
\text { proble } \\
\mathrm{m}\end{array}$ & $\begin{array}{c}\text { Proble } \\
\mathrm{m} \text { as } \\
\text { bad as } \\
\text { it can } \\
\text { be }\end{array}$ & $\begin{array}{c}\text { Most } \\
\text { importa } \\
\text { nt items }\end{array}$ \\
\hline 1 & $\begin{array}{l}\text { Need to blow } \\
\text { nose }\end{array}$ & 0 & 1 & 2 & 3 & 4 & 5 & {$[$ ] } \\
\hline 2 & Sneezing & 0 & 1 & 2 & 3 & 4 & 5 & {$[$ ] } \\
\hline 3 & Runny nose & 0 & 1 & 2 & 3 & 4 & 5 & {[]} \\
\hline 4 & Nasal blockage & 0 & 1 & 2 & 3 & 4 & 5 & {$[$ ] } \\
\hline 5 & $\begin{array}{l}\text { Decreased sense } \\
\text { of smell/ taste }\end{array}$ & 0 & 1 & 2 & 3 & 4 & 5 & {$[$ ] } \\
\hline 6 & Cough & 0 & 1 & 2 & 3 & 4 & 5 & {[]} \\
\hline 7 & Post nasal drips & 0 & 1 & 2 & 3 & 4 & 5 & {$[$ ] } \\
\hline 8 & $\begin{array}{l}\text { Thick nasal } \\
\text { discharge }\end{array}$ & 0 & 1 & 2 & 3 & 4 & 5 & [ ] \\
\hline 9 & Ear fullness & 0 & 1 & 2 & 3 & 4 & 5 & {$[$ [ ] } \\
\hline 10 & Dizziness & 0 & 1 & 2 & 3 & 4 & 5 & {[]} \\
\hline 11 & Ear pain & 0 & 1 & 2 & 3 & 4 & 5 & {[]} \\
\hline 12 & $\begin{array}{l}\text { Facial } \\
\text { pain/pressure }\end{array}$ & 0 & 1 & 2 & 3 & 4 & 5 & {$[$ ] } \\
\hline 13 & $\begin{array}{l}\text { Difficulty falling } \\
\text { as sleep }\end{array}$ & 0 & 1 & 2 & 3 & 4 & 5 & {$[$ ] } \\
\hline 14 & $\begin{array}{l}\text { Waking up at } \\
\text { night }\end{array}$ & 0 & 1 & 2 & 3 & 4 & 5 & {$[$ ] } \\
\hline 15 & $\begin{array}{l}\text { Lack of a good } \\
\text { night's sleep }\end{array}$ & 0 & 1 & 2 & 3 & 4 & 5 & {$[$ ] } \\
\hline 16 & Waking up tired & 0 & 1 & 2 & 3 & 4 & 5 & {$[$ ] } \\
\hline 17 & $\begin{array}{l}\text { Fatigue during } \\
\text { the day }\end{array}$ & 0 & 1 & 2 & 3 & 4 & 5 & {$[$ ] } \\
\hline 18 & $\begin{array}{l}\text { Reduced } \\
\text { productivity }\end{array}$ & 0 & 1 & 2 & 3 & 4 & 5 & {$[$ ] } \\
\hline 19 & $\begin{array}{l}\text { Reduced } \\
\text { concentration }\end{array}$ & 0 & 1 & 2 & 3 & 4 & 5 & [ ] \\
\hline 20 & $\begin{array}{l}\text { Frustated/ } \\
\text { restless/irritable }\end{array}$ & 0 & 1 & 2 & 3 & 4 & 5 & {$[$ ] } \\
\hline 21 & Sad & 0 & 1 & 2 & 3 & 4 & 5 & [ ] \\
\hline 22 & Embarassed & 0 & 1 & 2 & 3 & 4 & 5 & {[]} \\
\hline
\end{tabular}


Total :

TOTAL SCORE (all columns) :

\begin{tabular}{|c|c|}
\hline Score & Evaluation \\
\hline 0 to 14 & No Problem to mild Problem \\
\hline 15 an above & Moderate to Severe Problem \\
\hline
\end{tabular}

Each statement is given a value:

$0=$ no problem, $1=$ mild problem, $2=$ mild or slight problem, $3=$ moderate problem, $4=$ severe problem, 5 = as bad as it can be.

From the descriptions above, it shows that there are various anatomical variations of the nasal cavity and paranasal sinuses when doing paranasal sinuses CT scan. (Hamilos 2011, Hastan at all2011)

Identification for anatomical variations of the patient's paranasal sinuses determines the next management, the surgical approach to be carried out, as a guide for operators in performing surgery, prevents complications, determines the rate of recurrence and for post surgery follow-up which can also affect patient's quality of life. Seeing how importance to know description of anatomical variations on paranasal sinuses CT scan and currently, there are still a few operators who concern to these anatomical variations that are associated with patient's quality of life based on SNOT-22 score before performing surgery. (Pranita 2015, Rosenfeld at all 2015, Rudmik at all 2016)

\section{METHODS}

This study is a cross sectional study, to determine the correlation between the anatomical variations of nasal cavity and paranasal sinuses and the quality of life based on SNOT-22 score in the patients who underwent paranasal sinuses CT scan. The study population was patients who came to the radiology department for paranasal sinuses CT scan. The study samples were taken from the study population that has been identified and meets the criteria. The sampling was done by consecutive sampling, which is, all the patients who meet the study criteria are included in the study until the required sample size is met. Paranasal Sinuses CT scan Examination is a noncontrast imaging examination for anatomical structures of the nasal cavity, paranasal sinuses and surrounding structures. The patient is in prone position, the head is extended with the chin support the head, the gantry is then angulated (perpendicular to the infraorbitomeatal line) with a slice thickness of $3 \mathrm{~mm}$ per slice. Anatomical variations of the nasal cavity and paranasal sinuses are anatomical variations in the form of: frontal cells, agger nasi cells, ethmoid bulla, uncinate process, chonca bullosa, nasal septal deviation and Haller cells which are not an anatomical abnormality of the nasal cavity and paranasal sinuses. The agger nasi cells in paranasal sinuses CT scan examination are told to be an anatomical variation if a round or oval shape of the air cavity located below the frontal sinus and in the anterior frontal recess which is assessed on each side of the sinus. The 
frontal cells in paranasal sinuses CT scan examination are told to be an anatomical variation if there is a round or oval air cavity located in the anterior frontal recess, the inferior part of the frontal sinuses, which corresponds to the agger nasi air cavity and the frontal sinus cavity which is assessed on each side of the sinus. Ethmoid bullae in paranasal sinuses CT scan examination are told to be an anatomical variation if the largest ethmoid cells appear or a round or oval air cavity located behind the uncinate process which is separated from the uncinate process by a semilunaris hiatus and assessed on each side of the sinus. The uncinate process in paranasal sinuses CT scan examination is told to be an anatomical variation if the bone plate is thin and curved which is an extension of the posterior type of the lacrimal bone. If the uncinate process deviates to the lateral direction, it will press the infundibulum, while if it is medial it will press the middle meatus which is assessed on each side of the sinus. Concha bullosa in paranasal sinuses CT scan examination is told to be an anatomical variation if it appears pneumatization of the media concha, which can occur unilaterally or bilaterally. Nasal septal deviation in paranasal sinuses CT scan is told to be an anatomical variation if the coronal view shows nasal cavity deviate to the left or right of the midline. Haller cells on paranasal sinuses CT scan are told to be an anatomical variations if they see pneumatized anterior ethmoid cells on the medial roof of the maxillary sinuses, below the lamina papyracea and lateral to the uncinate process and assessed on each side of the sinuses. The data obtained are grouped according to study variables and presented in descriptive form, then the appropriate statistical method is selected and processed by the help of a computer. The statistical test was univariate analysis in which to analyze the data of each variable in study based on age, sex, anatomical variations (frontal cells, agger nasi cells, ethmoidal bulla, uncinate process, choncha bullosa, septal deviation, haller cells) and the SNOT-22 score, while the bivariate test in which to analyze the results of the correlation test between the presence or absence of anatomical variations of nasal cavity and paranasal sinuses and the quality of life based on SNOT-22 score in the patients who underwent paranasal sinuses CT scans, which were tested with T test, Chi Square test or Fisher's test, and also to analyze the correlation between the total anatomical variations of nasal cavity and paranasal sinuses and the quality of life based on SNOT-22 score in the patients who underwent paranasal sinuses CT scan were tested with Spearman's Rho test. Then the results was obtained and displayed in narrative and table form.

\section{RESULTS AND DISCUSSION}

Univariate analysis was to analyze the data for each variable in study based on age, sex, anatomical variations (frontal cells, agger nasi cells, ethmoid bulla, uncinate process, choncha bullosa, septal deviation, haller cells) and SNOT-22 scores. This univariate analysis is showed in Table 1, 2, 3 . 
Table 1. Frequency distribution of the patients who underwent paranasal sinuses CT scan based on age and sex.

\begin{tabular}{lccc}
\hline & & $\mathrm{n}$ & $\%$ \\
\hline Sex & Male & 17 & 47,2 \\
& Female & 19 & 52,8 \\
\hline & $17-25$ & 12 & 33,3 \\
& $26-35$ & 3 & 8,3 \\
Age (years) & $36-45$ & 13 & 36,1 \\
& $46-55$ & 4 & 11,1 \\
& $56-65$ & 1 & 8,3 \\
& $>65$ & 3 & 2,8 \\
\hline
\end{tabular}

Source : primary data

Table 1 shows that frequency distribution of the patients who underwent paranasal sinuses CT scan is based on age and sex. It can be seen that frequency distribution based on gender, it was more common in female 19 samples (52.8\%) compared to male 17 samples (47.2\%). The frequency distribution based on age was most common in age 36-45 years 13 samples $(36.1 \%)$.

Table 2. Anatomical variations distribution of the patients who underwent paranasal sinuses CT scan.

\begin{tabular}{lcccc}
\hline \multirow{2}{*}{ Anatomical variations } & \multicolumn{3}{c}{ No } & \multicolumn{3}{c}{ Yes } \\
\cline { 2 - 5 } & $\mathrm{n}$ & $\%$ & $\mathrm{n}$ & $\%$ \\
\hline Septal deviation & 7 & 19,4 & 29 & 80,6 \\
Concha bullosa & 21 & 58,3 & 15 & 41,7 \\
Ethmoid bulla & 25 & 69,4 & 11 & 30,6 \\
Uncinate process & 28 & 77,8 & 8 & 22,2 \\
Haller cells & 32 & 88,9 & 4 & 11,1 \\
Frontal cells & 33 & 91,7 & 3 & 8,3 \\
Agger nasi cells & 34 & 94,4 & 2 & 5,6 \\
\hline
\end{tabular}

Source : primary data

Table 2 shows anatomical variations distribution in the patients who underwent paranasal sinuses CT scan. The most common anatomical variations was septal deviation 29 samples (80.6\%), followed by concha bullosa 15 samples (41.7\%), and ethmoid bulla 11 samples (30.6\%).

Table 3. Description of quality of life based on SNOT-22 score in the patients who underwent paranasal sinuses CT scan.

\begin{tabular}{lcc}
\hline \multicolumn{1}{c}{ SNOT-22 } & $\mathrm{n}$ & $\%$ \\
\hline Normal - Mild (0-14) & 4 & 11,1 \\
Moderate - Severe $(\geq 15)$ & 32 & 88,9 \\
\hline
\end{tabular}


Table 3 shows description of quality of life based on SNOT-22 score in the patients who underwent paranasal sinuses CT scan, it was found that 32 subjects $(88.9 \%)$ were in Moderate Severe $(\geq 15)$ group.

The results of correlation test between the presence or absence of anatomical variations of nasal cavity and paranasal sinuses and the quality of life based on SNOT-22 score in the patients who underwent paranasal sinuses CT scan were tested using Chi Square test or Fisher's test, are shown in table 4 below:

Table 4. Anatomical variations description of frontal cells, agger cells, ethmoid bulla, uncinate process, choncha bullosa, septal deviation, haller cell with SNOT-22 score in the patients who underwent paranasal sinuses CT scan.

\begin{tabular}{|c|c|c|c|c|c|c|c|c|}
\hline \multirow{2}{*}{$\begin{array}{l}\text { Anatomical } \\
\text { variations }\end{array}$} & & \multicolumn{4}{|c|}{ SNOT-22 } & \multirow[b]{2}{*}{ Total } & \multirow[b]{2}{*}{$\%$} & \multirow[b]{2}{*}{$\mathrm{P}$} \\
\hline & & $\begin{array}{l}\text { Normal } \\
\text { - Mild }\end{array}$ & $\%$ & $\begin{array}{l}\text { Moderate } \\
\text { - Severe }\end{array}$ & $\%$ & & & \\
\hline \multirow{2}{*}{$\begin{array}{l}\text { Frontal } \\
\text { cells }\end{array}$} & Yes & 1 & 33,3 & 2 & 66,7 & 3 & 100 & \multirow{3}{*}{0,305} \\
\hline & No & 3 & 9,1 & 30 & 90,9 & 33 & 100 & \\
\hline Total & & 4 & 11,1 & 32 & 88,9 & 36 & 100 & \\
\hline \multirow{2}{*}{$\begin{array}{l}\text { Agger nasi } \\
\text { cells }\end{array}$} & Yes & 0 & 0,0 & 2 & 100 & 2 & 100 & \multirow{3}{*}{1,000} \\
\hline & No & 4 & 11,8 & 30 & 88,2 & 34 & 100 & \\
\hline Total & & 4 & 11,1 & 32 & 88,9 & 36 & 100 & \\
\hline \multirow{2}{*}{$\begin{array}{l}\text { Ethmoid } \\
\text { bulla }\end{array}$} & Yes & 0 & 0,0 & 11 & 100 & 11 & 100 & \multirow{3}{*}{0,290} \\
\hline & No & 4 & 16,0 & 21 & 84,0 & 25 & 100 & \\
\hline Total & & 4 & 11,1 & 32 & 88,9 & 36 & 100 & \\
\hline \multirow{2}{*}{$\begin{array}{l}\text { Uncinate } \\
\text { process }\end{array}$} & Yes & 1 & 12,5 & 7 & 87,5 & 8 & 100 & \multirow{3}{*}{1,000} \\
\hline & No & 3 & 10,7 & 25 & 89,3 & 28 & 100 & \\
\hline Total & & 4 & 11,1 & 32 & 88,9 & 36 & 100 & \\
\hline \multirow{2}{*}{$\begin{array}{l}\text { Choncha } \\
\text { bullosa }\end{array}$} & Yes & 0 & 0,0 & 15 & 100 & 15 & 100 & \multirow{3}{*}{0,125} \\
\hline & No & 4 & 19,0 & 17 & 81,0 & 21 & 100 & \\
\hline Total & & 4 & 11,1 & 32 & 88,9 & 36 & 100 & \\
\hline \multirow{2}{*}{$\begin{array}{l}\text { Septal } \\
\text { deviation }\end{array}$} & Yes & 1 & 3,4 & 28 & 96,6 & 29 & 100 & \multirow{3}{*}{0,018} \\
\hline & No & 3 & 42,9 & 4 & 57,1 & 7 & 100 & \\
\hline Total & & 4 & 11,1 & 32 & 88,9 & 36 & 100 & \\
\hline \multirow{2}{*}{ Haller cells } & Yes & 0 & 0,0 & 4 & 100 & 4 & 100 & \multirow{3}{*}{1,000} \\
\hline & No & 4 & 12,5 & 28 & 87,5 & 32 & 100 & \\
\hline Total & & 4 & 11,1 & 32 & 88,9 & 36 & 100 & \\
\hline
\end{tabular}

Description: Chi-Square Test or Fisher's Test

Source : primary data 
Table 4 shows anatomical variations descriptions of frontal cells with SNOT-22 score in the patients who underwent paranasal sinuses CT scan in 36 samples, it was found that 1 subject (33.3\%) with frontal cells had normal - mild SNOT-22 score, and 2 subjects (66.7\%) with frontal cells had moderate - severe SNOT-22 score, where the p value $(>0.05)$, which means that there is no correlation between frontal cell anatomical variations and quality of life based on SNOT-22 score. Agger nasi cells with SNOT-22 score in the patients who underwent paranasal sinuses CT scan in 36 patients, it was found that 4 subjects $(11.8 \%)$ without agger nasi cells had normal - mild SNOT-22 score, and 30 subjects (88.9\%) without agger nasi cells had moderate - severe SNOT-22 score, where the $\mathrm{p}$ value $(>0.05)$ which means there is no correlation between agger nasi cells anatomical variation and quality of life based on SNOT-22 score. Ethmoid bulla with a SNOT-22 score in the patients who underwent paranasal sinuses CT scan in 36 patients, it was found that 4 subjects $(16.0 \%)$ without ethmoid bullae had normal - mild SNOT-22 score, and 21 subjects $(84.0 \%)$ without ethmoid bullae had moderate - severe SNOT-22 score, where the p value $(>0.05)$ which means that there is no correlation between ethmoid bulla anatomical variations and quality of life based on SNOT-22 score. Uncinate process with SNOT-22 score in the patients who underwent paranasal sinuses CT scan in 36 patients, it was found that 1 subject $(12.5 \%)$ with uncinate process had normal - mild SNOT-22 score, and 7 subjects $(87.5 \%)$ with uncinate process had moderate - severe, where the $\mathrm{p}$ value $(>0.05)$ which means there is no correlation between uncinate process anatomical variation and quality of life based on SNOT-22 score. Concha bullosa with SNOT-22 score in the patients who underwent paranasal sinuses CT scan in 36 patients, it was found that 4 subjects $(19.0 \%)$ without concha bullosa had normal - mild SNOT-22 scores, 17 subjects $(81.0 \%)$ without concha bullosa had moderate - severe SNOT-22 scores, where the p value $(>0.05)$ which means there is no correlation between choncha bullosa anatomical variation and quality of life based on SNOT-22 score. Septal deviation with SNOT-22 score in the patients who underwent paranasal sinuses CT scan in 36 patients, it was found that 1 subject $(3.4 \%)$ with septal deviation had normal - mild SNOT-22 score, 28 subjects (96.6\%) with septal deviation had moderate - severe, where the $\mathrm{p}$ value $(<0.05)$ which means that there is a correlation between septal deviation anatomical variation and quality of life based on SNOT-22 score. Haller cells with SNOT-22 scores in the patients who underwent paranasal sinuses CT scan in 36 patients, it was found that 4 subjects $(12.5 \%)$ without Haller cells had normal - mild SNOT-22 scores, 28 subjects $(87.5 \%)$ without Haller cells had moderate - severe SNOT-22 scores, where the p value $(>0.05)$ which means there is no correlation between the Haller cells anatomical variations and quality of life based on SNOT-22 score.

The correlation between the presence or absence of anatomical variations of the nasal cavity and paranasal sinuses with the quality of life based on SNOT-22 score in the patients who underwent paranasal sinuses CT scan tested using T-Independent test is shown in table 5 below : 
Table 5. Mean values and correlation between frontal cell, agger nasi cells, ethmoid bulla, uncinate process, choncha bulosa, septal deviation, sel haller anatomical variations and quality of life based on SNOT-22 score in the patients who underwent paranasal sinuses CT scan.

\begin{tabular}{|c|c|c|c|c|}
\hline \multirow{2}{*}{\multicolumn{2}{|c|}{ Anatomical variations }} & \multicolumn{3}{|c|}{ SNOT-22 } \\
\hline & & $\mathrm{n}$ & mean & $\mathrm{P}$ \\
\hline \multirow{2}{*}{ Frontal cells } & Yes & 3 & 62,00 & 0,220 \\
\hline & No & 33 & 46,55 & \\
\hline \multirow{2}{*}{ Agger nasi cells } & Yes & 2 & 53,00 & 0,722 \\
\hline & No & 34 & 47,53 & \\
\hline \multirow{2}{*}{ Ethmoid bulla } & Yes & 11 & 51,27 & 0,516 \\
\hline & No & 25 & 46,32 & \\
\hline \multirow{2}{*}{ Uncinate process } & Yes & 8 & 49,25 & 0,830 \\
\hline & No & 28 & 47,43 & \\
\hline \multirow{2}{*}{ Concha bullosa } & Yes & 15 & 56,60 & 0,029 \\
\hline & No & 21 & 41,57 & \\
\hline \multirow{2}{*}{ Septal Deviation } & Yes & 29 & 52,24 & 0,007 \\
\hline & No & 7 & 29,57 & \\
\hline \multirow{2}{*}{ Sel Haller } & Yes & 4 & 48,25 & 0,967 \\
\hline & No & 32 & 47,78 & \\
\hline
\end{tabular}

Description : T Test

Source : primary data

Table 5 shows mean values and correlation between frontal cell anatomical variations and quality of life based on SNOT-22 score in the patients who underwent paranasal sinuses CT scan in 36 samples, it was found that the absent of frontal cells $n$ (33), mean (46.55), the existing of frontal cells $\mathrm{n}$ (3), mean (62.00), and the correlation value for the whole sample is $\mathrm{p}(0.220)$, where the $\mathrm{p}$ value $(>0.05)$ which means there is no correlation between frontal cell anatomical variations and quality of life based on SNOT-22 score. Agger nasi cells anatomical variations and quality of life based on SNOT-22 scores in the patients who underwent paranasal sinuses CT scan in 36 samples, it was found that the absent of agger nasi cells $n$ (34), mean (47.53), the existing of agger nasi cells $n$ (2), mean (53.00), and the correlation value of the whole sample is $\mathrm{p}(0.722)$ where the $\mathrm{p}$ value ( $>$ $0.05)$ which means there is no correlation between agger nasi cells anatomical variations and quality of life based on SNOT-22 score. Ethmoid bullae anatomical variations and quality of life based on SNOT-22 score in the patients who underwent paranasal sinuses CT scan in 36 samples, it was found that the absent of ethmoid bulla $\mathrm{n}(25)$, mean $(46,43)$, the existing of ethmoid bulla $\mathrm{n}(11)$, mean (51.27), and the correlation value of the whole sample is $\mathrm{p}(0.516)$, where the p value $(>0.05)$ which means there is no correlation between ethmoid bulla anatomical variations and quality of life based on SNOT-22 score. Uncinate process anatomical variations and quality of life based on SNOT-22 scores in the patients who underwent paranasal sinuses CT scan in 36 samples, it was 
found that the absent of uncinate process $n(28)$, mean (47,43), the existing of the uncinate process $\mathrm{n}(8)$, mean (49.25), and the correlation value of the whole sample is $\mathrm{p}(0.830)$, where the $\mathrm{p}$ value $(>$ $0.05)$ which means that there is no correlation between uncinate process anatomical variations and quality of life based on a SNOT-22 score. Concha bullosa anatomical variations and quality of life based on SNOT-22 scores in patients who underwent paranasal sinuses CT scan in 36 samples, it was found that the absent of concha bullosa $n$ (21), mean (41.57), the existing of concha bullosa $n$ (15), the mean (56.60), and the correlation value of the whole sample is $\mathrm{p}(0.029)$ where the $\mathrm{p}$ value $(<0.05)$ means there is a correlation between concha bullosa anatomical variations and quality of life based on SNOT-22 score. Septal deviation anatomical variation and quality of life based on SNOT-22 score in the patients who underwent paranasal sinuses CT scan in 36 samples, it was found that the absent of septal deviation $\mathrm{n}(7)$, mean $(29,57)$, the existing of septal deviation $\mathrm{n}$ (29), mean (52.24), and the correlation value for the whole sample is $\mathrm{p}(0.007)$ where the $\mathrm{p}$ value $(<0.05)$ which means there is a correlation between septal deviation anatomical variations and quality of life based on SNOT-22 score. Haller cells anatomical variations and quality of life based on SNOT-22 scores in patients who underwent paranasal sinuses CT scan in 36 samples, it was found that the absent of Heller cells $\mathrm{n}$ (32), mean (47.78), the existing of septal deviation $\mathrm{n}$ (4), mean (48.25), and the correlation value of the whole sample is $\mathrm{p}(0.967)$ where the $\mathrm{p}$ value is $(>$ 0.05), which means there is no correlation between Haller cells anatomical variations and quality of life based on a SNOT-22 score.

The correlation between the total anatomical variation of nasal cavity and paranasal sinuses and the quality of life based on SNOT-22 score in the patients who underwent paranasal sinuses CT scan were tested using Spearman's Rho test is shown in table 6 below:

Table 6. Correlation between total anatomical variation and quality of life based on SNOT-22 score in the patients who underwent paranasal sinuses CT scan.

\begin{tabular}{lcc}
\hline \multirow{2}{*}{ Total } & \multicolumn{2}{c}{ SNOT-22 } \\
\cline { 2 - 3 } & $\mathrm{p}$ & $\mathrm{r}$ \\
\hline Anatomical variations & 0,025 & 0,372
\end{tabular}

Description : Spearman's Rho test

Source : primary data

Table 6 shows correlation between total anatomical variation and quality of life based on the SNOT-22 score in the patients who underwent paranasal sinuses CT scan in 36 samples, there was a weak correlation between total anatomical variation and quality of life based on SNOT-22 score in the patients who underwent paranasalis sinuses CT scan with the p value $(0.025)$ where the $\mathrm{p}$ value $(<0.05)$ 


\section{CONCLUSION}

The most common anatomical variations of the nasal cavity and paranasal sinuses in the patients who underwent paranasal sinuses CT scan are septal deviation and concha bullosa. There was a significant correlation between total anatomical variation and quality of life based on SNOT22 score in the patients who underwent paranasal sinuses CT scan. There was no correlation between the anatomical variations of frontal cells, agger nasi cells, ethmoid bulla, uncinate process and haller cells and the quality of life based on SNOT-22 score in the patients who underwent paranasal sinuses CT scan.

\section{REFERENCES}

Abul-Kasim K, Strombeck A, Sahlstrand-Johnson P. (2011) Low-dose computed tomography of the paranasal sinuses: radiation doses and reliability analysis. Am J Otolaryngol

Aghdas, (2018). Sinuses paranasalis, radiologic anatomy. The patient health.

Akdis CA, Bachert C, Cingi C, et al. (2013) Endotypes and phenotypes of chronic rhinosinusitis: a PRACTALL document of the European Academy of Allergy and Clinical Immunology and the American Academy of Allergy, Asthma \& Immunology. The Journal of allergy and clinical immunology.

Alt JA, DeConde AS, Mace JC, Steele TO, Orlandi RR, Smith TL. (2015) Quality of Life in Patients With Chronic Rhinosinusitis and Sleep Dysfunction Undergoing Endoscopic Sinus Surgery. JAMA Otolaryngol Head Neck Surg.

Banglawala SM, Schlosser RJ, Storck T, Morella K, Chandra R, Khetani J, et al. (2015) Qualitative development of the Sinus Control Test: a survey evaluating sinus symptom control. Int Forum Allergy Rhinol.

Barros E, Silvia A, Sousa Vieira A. (2012) Prevalence and characteristic of rhinosinusitis at primary health care in Portugal. Rev Port ORL.

DeConde AS, Mace JC, Bodner TE, et al. (2014) SNOT-22 quality of life domains differentially predict treatment modality selection in chronic rhinosinusitis. Int Forum Allergy Rhinol.

Farhood Z, Schlosser RJ, Pearse ME, Storck KA, Nguyen SA, Soler ZM. (2016) Twenty-two-item Sino-Nasal Outcome Test in a control population : a cross-sectional study and systemic review. Int Forum Allergy Rhinol.

Fokkens w, Lund Vm Bachert C, Clement P, Hellings P, Holmstrom M, Jones N, et al.(2012) European Position Paper on Rhinosinusitis and Nasal Polyps. Rhinology.

Hamilos D.(2011) Chronic rhinosinusitis: epidemiology and medical management. J Allergy Clin Immunol. 
Hastan D1, Newson RB, dkk. (2011) Chronic rhinosinusitis in Europe-an underestimated disease. Allergy.

Johnson JT, Rosen CA, editor.(2014) Bailey's Head and Neck Surgery Otolaryngology. 5Th Edition. Vol-1. Philadelphia : Lippincott Williams \&

Wilkins.

Juanda, (2017). Scoring SNOt-22. Symptoms and outcome sino-nasal statements. Indonesia.

Lachanas V, (2014). Tsea M, Tsiovaka S, Hajiioannou J, Skoulakis C, Bizakis J. The Sino-nasal Outcome Test (SNOT-22) : Validation for Greek Patients. Eur Acrh Otorhinolaryngol. Pages :1-6.

Leung, (2014). Anatomy of cavum nasi and sinuses paranasalis. China.

Lupoi D, Sarafoleanu C. (2012) SNOT-20 and VAS Questionnaires in Establishing The Success of Different Surgical Approaches in Chronic Rhinosinusitis. Romanian Journal of Rhinology.

Naidoo Y, Tan N, Singhal D, Wormald PJ. (2013) Chronic rhinosinusitis assess-ment using the Adelaide Disease Severity Score. J Laryngol Otol

Pranitasari, (2015). Rinology disease, ENT-KL health sciences, Faculty of Medicine, University of Indonesia, Jakarta.

Rosenfeld RM, Piccirillo JF, Chandrasekhar SS, Brook I, Kumar KA, Kramper M, et al. (2015) Clinical Practice Guideline (Update) : Adult Sinusitis. Otolaryngology-Head and Neck Surgery.

Rudmik L, Soler ZM, Hopkins C, et al. (2016) Defining Appropriateness Criteria for Endoscopic Sinus Surgery During Management of Uncomplicated Adult Chronic Rhinosinusitis: A RAND/UCLA Appropriateness Study. Int Forum Allergy Rhinol.

Shindy MF, El-Sayed MA. (2015). Effectiveness of Office Nasal Endoscopy as Preliminary Diagnostic Tool: A Comparative Study versus CT Sinuses Imaging. J Am Sci. Pages : 5763.

Simopoulos E, Katotomichelakis M, Gouveris H, Tripsianis G, Livaditis M, Danielides V. (2012) Olfaction-associated quality of life in chronic rhinosinusitis: adap- tation and validation of an olfaction-specific questionnaire. Laryngoscope

Soler ZM, Rudmik L, Hwang PH, Mace JC, Schlosser RJ, Smith TL. (2013) Patient-centered decision making in the treatment of chronic rhinosinusitis. Laryngoscope.

Walsh WE and Kern RC. (2014) Sinonasal Anatomy and Physiology. Dalam : Bailey BJ and Johnson JT, penyunting. Head \& Neck Surgery Otolaryngology. 5Th Edition. Vol-1. Philadelpia: Lippincott Williams \& Wilkins; Pages: 359-370.

Wang DY, Wardani RS, SinghK, Thanaviratananich S, Vicente G, Xu G, et al. (2011) A survey on the management of acute rhinosinusitis among Asian physicians. Rhinology. 